\title{
INVESTIGATION OF THE EFFECT OF STEROIDAL IMIDAZOHETEROCYCLES HORMONE DERIVATIVES ON JEG-3 TROPHOBLAST CELLS OF CHORIOCARCINOMA
}

\author{
Jovana V. Todosijević1, Alexander M. Scherbakov², \\ Yulia A. Volkova ${ }^{3}$, Vladimir B Jurišić ${ }^{4 *}$
}

\author{
${ }^{1}$ University of Kragujevac, Faculty of Science, Department of Biology and Ecology, \\ Radoja Domanovića 12, 34000 Kragujevac, Serbia \\ ${ }^{2}$ NN Blokhin National Medical Research Center of Oncology, \\ Department of experimental Tumor Biology, 24 Kashirskoe shosse, 115522, Moscow, Russia \\ ${ }^{3}$ N.D. Zelinsky Institute of Organic Chemistry, Russian Academy of Sciences, \\ 47 Leninsky prosp., 119991 Moscow, Russia \\ ${ }^{4}$ Unversity of Kragujevac, Faculty of Medical Sciences, Svetozara Markovića 69, \\ 34000 Kragujevac, Serbia \\ *Corresponding author; E-mail: jurisicvladimir@gmail.com
}

(Received March 28, 2021; Accepted April 8, 2021)

\begin{abstract}
This study aimed to examine the biological activities of unique steroid hormone derivatives - steroidal imidazoheterocycles. The activity synthesized steroidal compounds were tested for the viability of JEG-3 trophoblast cells of choriocarcinoma. The results of the MTT cytotoxicity test showed that most of the examined steroidal imidazoheterocycles act proliferatively on the JEG-3 cell line, except (E, F, and J). Antiproliferative activity of these derivates is probably influenced by different substituents at position 17-C atom in the chemical structure of the hormone and by different substituents on the oxygen atom of acetamide group in the hormone molecule. In order to better confirm the antiproliferative activity of these derivatives, it is necessary to performed complex research on a large panel of cancer cell lines and by different assay.
\end{abstract}

Keywords: JEG-3, steroidal imidazoheterocycles, choricarcinoma, MTT.

\section{INTRODUCTION}

The placenta is one of the main tissues that synthesize steroid hormones and affect the normal maintenance of pregnancy and fetal development (KARAHODA et al., 2021). Investigations of the mechanisms of synthesis, metabolism and secretion of steroid hormones are very important because disturbance of steroid hormones during pregnancy can lead to various disorders. The most common disorders are gestational diabetes, preeclampsia, Intrauterine Growth Restriction, and Gestational trophoblastic diseases (GTD) (SOLANO and ARCK, 2020).

Gestational trophoblastic diseases occur due to abnormal, proliferating transformation of placental cells (trophoblasts). Gestational trophoblastic neoplasia (GTN) is a malignant 
formation of GTD and includes invasive moles, epithelioid trophoblastic tumor (ETT), placental site trophoblastic tumor (PSTT) and choriocarcinoma (LURAIN, 2010).

Choriocarcinoma is a rare, highly malignant germ cell carcinoma (BENTLEY, 2003). There are two types of choriocarcinoma, namely gestational (GC) and non-gestational (NGC) which differentiate in the genetic profile, morphology, pathophysiology and prognosis (Mello et al., 2017).

Choriocarcinoma research provides very important information on the etiology, pathogenesis and potential therapy. A very important alternative to research in patients with choriocarcinoma is immortalized trophoblast cells grown in vitro. Research methods on cell lines are very important because it is possible to repeat experiments several times and they can test the whole spectrum of bioactive substances of natural or artificial origin. The three most widely used cell lines for placental choriocarcinoma are BeWo, Jar, and Jeg-3 (ORENDI et al., 2011). In this research, the model system for investigating the effects of substances obtained synthetically is the JEG-3 choriocarcinoma cell line.

Many natural and synthetic substances have been tested in the placental choriocarcinoma cell line. Some of them are daidzein, neuropeptide Y, fungicide ziram (CHEN et al., 2017; MATIĆ et al., 2017; ZHENG et al., 2018). There is an even larger number of studies on the influence of steroid hormones and their derivatives on the JEG-3 cell line, but also on the modulation of their synthesis (LONG et al., 1998; HoNKISZ and WóJTOWICZ, 2015; XU et al., 2019).

Studies on steroid hormones and their derivatives have brought many important conclusions about the proliferation, migration, metastasis, and apoptosis of placental choriocarcinoma cells. Screening of 10 newly synthesized steroid hormones could lead to isolation of potential substances that would improve the treatment of patients with placental choriocarcinoma.

\section{MATERIALS AND METHODS}

\section{Chemicals}

In this study, the activity of ten new steroidal imidazoheterocycles on the placental choriocarcinoma cell line was examined. Tested compounds were synthesized on N.D. Zelinsky Institute of Organic Chemistry, Russian Academy of Sciences. Steroidal imidazo[1,2-a]pyridines were synthesized from 2-aminopyridines and steroidal ketones in aerobic conditions with Fe (III) -Catalyzed synthesis as described in the previous paper. (SAMANTA et al., 2020).

\section{Cell preparation and culturing}

In this study, the effect of steroidal imidazoheterocycles was tested on a human cytotrophoblastic choriocarcinoma cell line JEG-3 (American Type Culture Collection). Choriocarcinoma cells were grown in DMEM medium (Dulbecco's modified Eagle medium, GIBCO) in $75 \mathrm{~cm}^{2}$ flasks up to $80 \%$ coverage. JEG-3 cells were seeded in 96-well plates, 10.000 cells per well. The study included ten different steroidal imidazoheterocycles (Fig. 1) at six different concentrations: $100 \mu \mathrm{M}, 10 \mu \mathrm{M}, 1 \mu \mathrm{M}, 100 \mathrm{nM}, 10 \mathrm{nM}$, and $1 \mathrm{nM}$.

The treated cells in microtiter plates were left in the Medline $\mathrm{CO}_{2}$ incubator until the treatment time expired. Cells were exposed to the steroidal imidazoheterocycles for $24 \mathrm{~h}$ and $72 \mathrm{~h}$. At the end of the treatment period, it was necessary to examine the effect of the tested substances. 


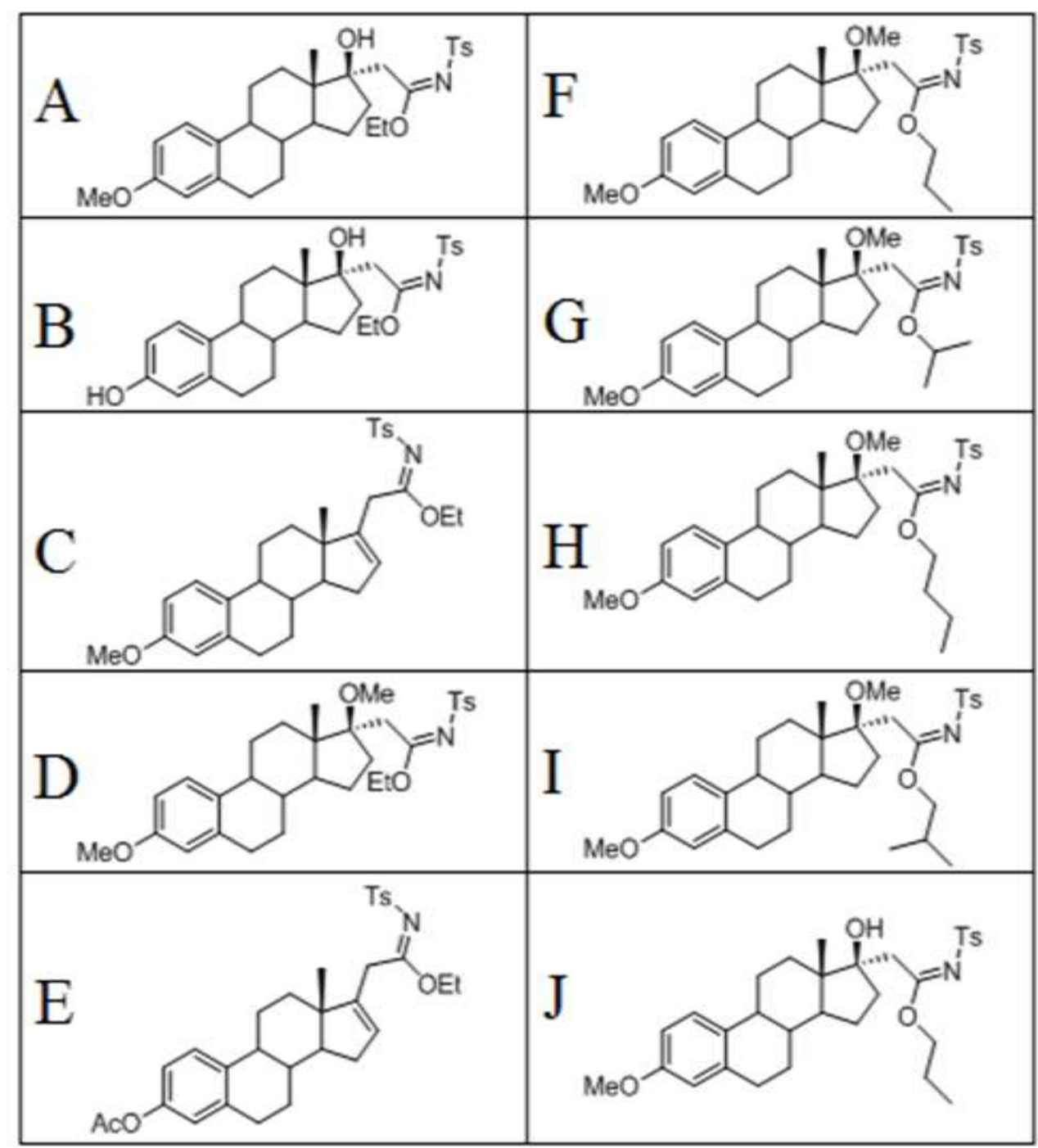

Figure 1. Steroid hormone derivatives.

\section{MTT assay}

The effect of steroidal imidazoheterocycles on the viability of the JEG-3 cell line was examined using the MTT assay (MOSMANN, 1983). MTT (3-(4,5-Dimethylthiazol-2-yl)-2,5diphenyl tetrazolium bromide) is a substance that is absorbed by living cells and converted into a water-insoluble formazan with the help of mitochondrial reductase. To each of the wells was added 100 MTT solution $(5 \mathrm{mg} / \mathrm{ml})$ and the plates were left to incubate at $37^{\circ} \mathrm{C}$ in a Medline $\mathrm{CO}_{2}$ incubator for 2 hours. After the incubation period, DMSO (Dimethyl Sulfoxide) was added to dissolve the formazan crystals. Absorbance (Abs) was measured on an ELISA microtiter plate reader (RT-21000C), and the percentage of cell viability was determined by the formula:

Abs (treated cells) / Abs (untreated cells-control) x 100.

\section{Statistical analysis}

The biological activity of steroidal imidazoheterocycles was examined in two experiments, performed in triplicate for each dose. The obtained results are expressed as mean \pm SE. Correlation between variables was obtained using the statistical software package SPSS (Chicago, IL) (SPSS for Windows, ver. 17, 2008). Statistical significance * was determined 
using one-way ANOVA test for multiple comparisons. A value of $\mathrm{p}<0.05$ was considered significant.

\section{RESULTS AND DISCUSSION}

The results obtained by analyzing the cytotoxicity of newly synthesized steroidal imidazoheterocycles (A-J) using the MTT cell viability test are presented graphically. The effect of each of the ten substances was tested at six different concentrations $(100 \mu \mathrm{M}, 10 \mu \mathrm{M}, 1$ $\mu \mathrm{M}, 100 \mathrm{nM}, 10 \mathrm{nM}$, and $1 \mathrm{nM})$ and at two exposure times ( $24 \mathrm{~h}$ and $72 \mathrm{~h}$ ). Figure 2 shows the effect of the tested steroidal imidazoheterocycles in short-term treatment ( $24 \mathrm{~h})$.

The results of the effect of steroidal imidazoheterocycles on the viability of the JEG-3 cell line after long-term treatment $(72 \mathrm{~h})$ are shown in Figure 3. The results of the effect of steroidal imidazoheterocycles on the viability of the JEG-3 cell line after long-term treatment (72 h) are shown in Figure 3.

After statistical processing, the results showed that synthetically obtained steroid imidazoheterocycles stimulated JEG-3 cells to increase proliferation, except the E, I, and J (Figs. 1 and 2).

Steroids containing various heterocycles such as imidazole, pyrazole and thiazole have a wide range of applications in medicine and their structural modifications give potentially new therapeutic agents (DEEP et al., 2017). Synthesis and investigation of biological activities of imidazopyridine derivatives are used in medicine and oncology. Previous data have shown that these derivatives can inhibit cell growth and key signaling molecules such as EGFR, VEGFR or PI3K (GOEL et al., 2016).

Biological activity has been demonstrated for a large number of compounds from the group of nitrogen imidazopyridine. These derivatives may have antiparasitic, antimicrobial, anti-inflammatory, anti-asthmatic, and anticancer activity (ENGUEHARD-GUEIFFIER et al., 2007; BAVISKAR et al., 2015; SCHERBAKOv et al., 2018; SAMANTA et al., 2020).

In this work, for the first time, as far as we know, the activity of ten newly synthesized imidazoheterocycles on the JEG-3 cell line was examined. Previous studies have examined a series of different derivatives but only in the breast cancer and prostate cancer cell line (RASSOKHINA et al., 2016). The cytotoxic effect was demonstrated only on the MCF-7 breast cancer cell line at the micromolar level.

However, the results obtained in this study showed that the tested imidazopyridine derivatives on the JEG-3 cell line show an increase in proliferation and only derivatives labelled as E, I, and J have a statistically significant antiproliferative effect. These derivatives have $\mathrm{C}-17$ substituted steroidal $\mathrm{N}$ - sulfonylimidates synthesized using $\mathrm{Cu}$-catalyzed azideealkyne cycloaddition. The compound I at five of six concentrations showed an antiproliferative effect after $72 \mathrm{~h}$ cultures, while substance $\mathrm{J}$ had an antiproliferative activity at all six concentrations at both exposure times.

The results of the tested imidazopyridine derivatives in the highest concentration of $100 \mu \mathrm{M}$ after long-term treatment of $72 \mathrm{~h}$ show that under these conditions substances $\mathrm{D}, \mathrm{E}, \mathrm{F}$ and $\mathbf{J}$ show statistically significant antiproliferative activity. A comparative presentation of the effects of all ten tested derivatives in the highest concentration $(100 \mu \mathrm{M})$ is shown in the graph (Fig. 4). 

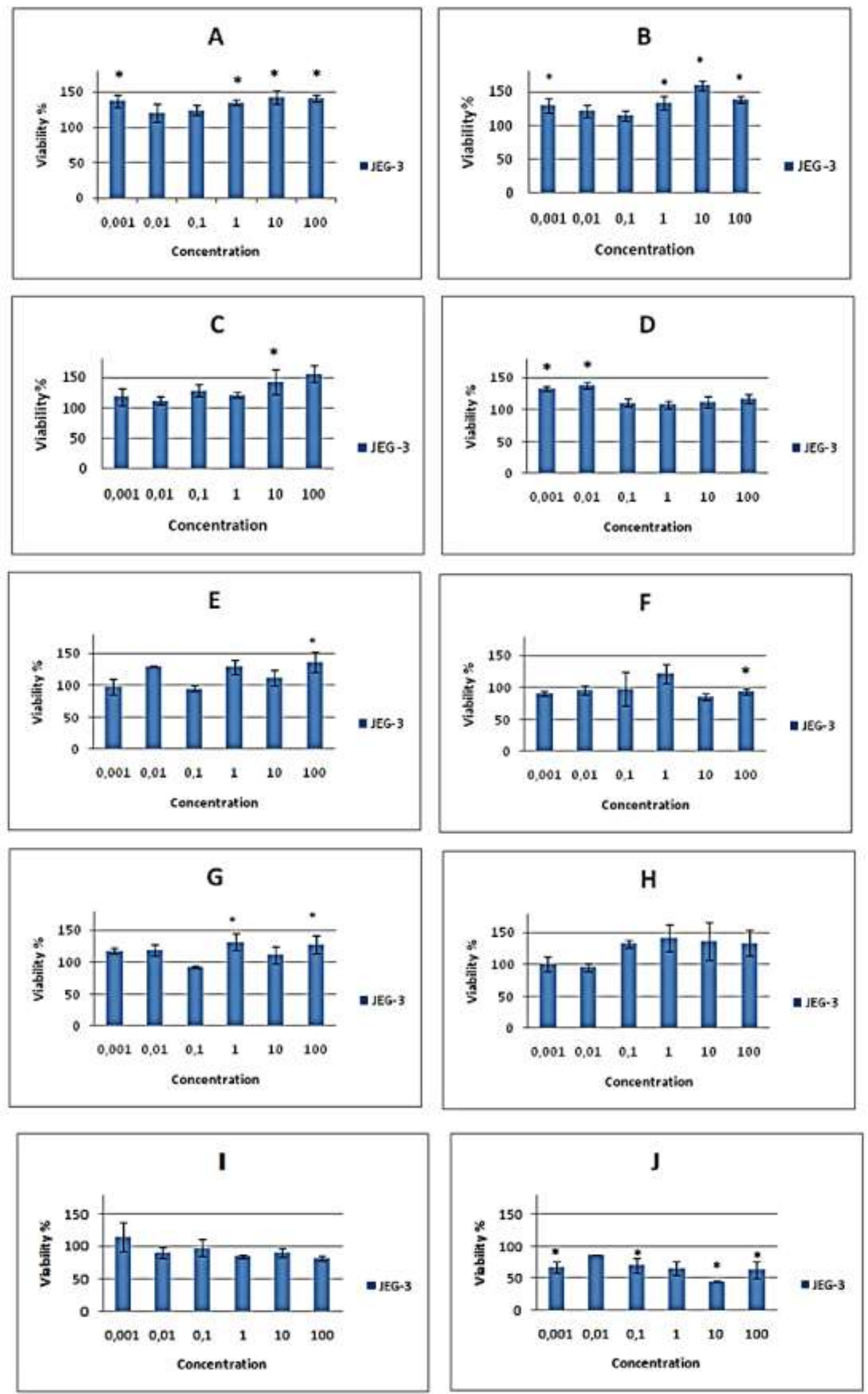

Figure 2. Effects of short-term ( $24 \mathrm{~h})$ treatment of different concentrations of steroidal imidazoheterocycles on JEG-3 choriocarcinoma cell line. 

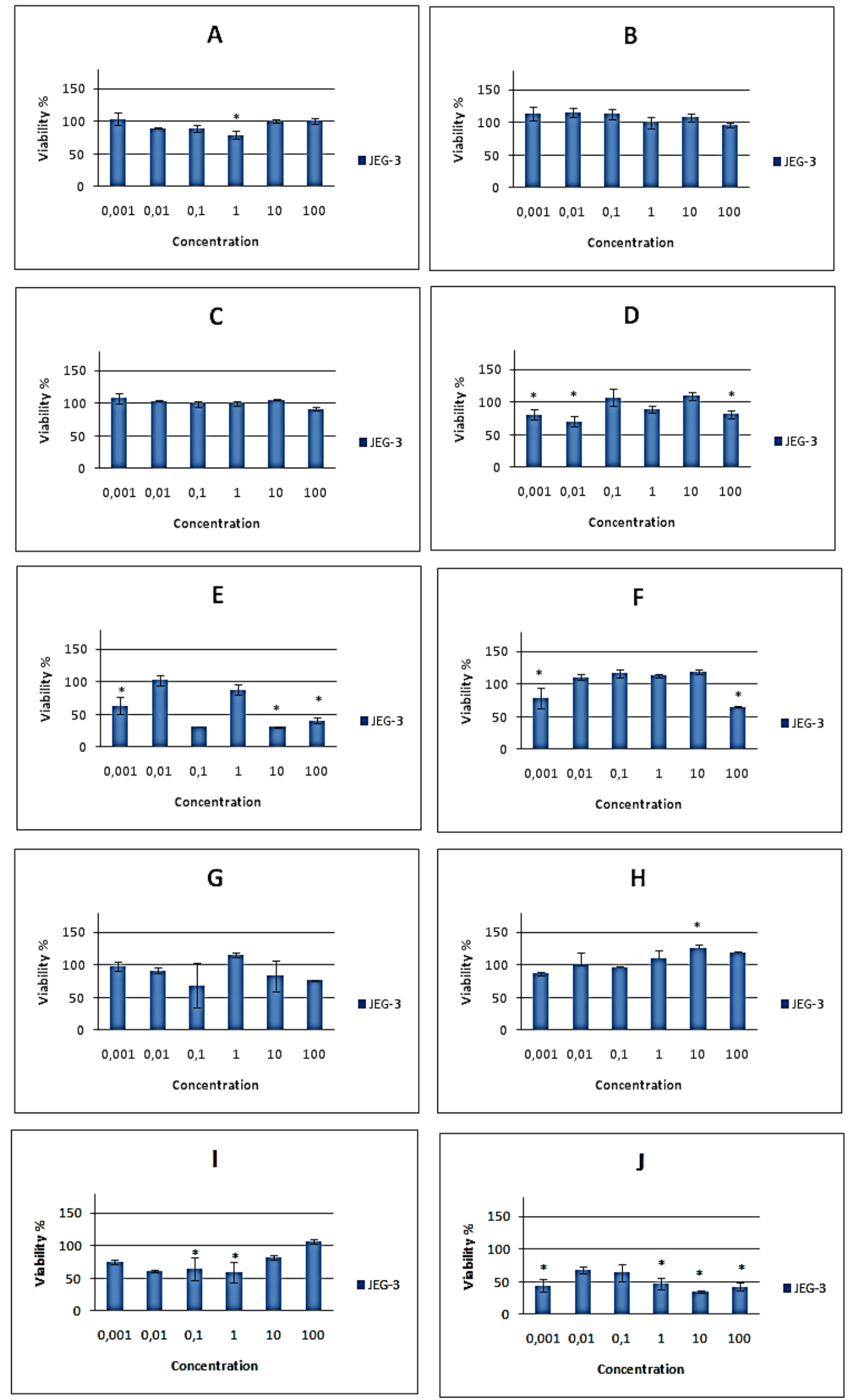

Figure 3. Effects of long-term ( $72 \mathrm{~h})$ treatment of different concentrations of steroidal imidazoheterocycles on JEG-3 choriocarcinoma cell line. 


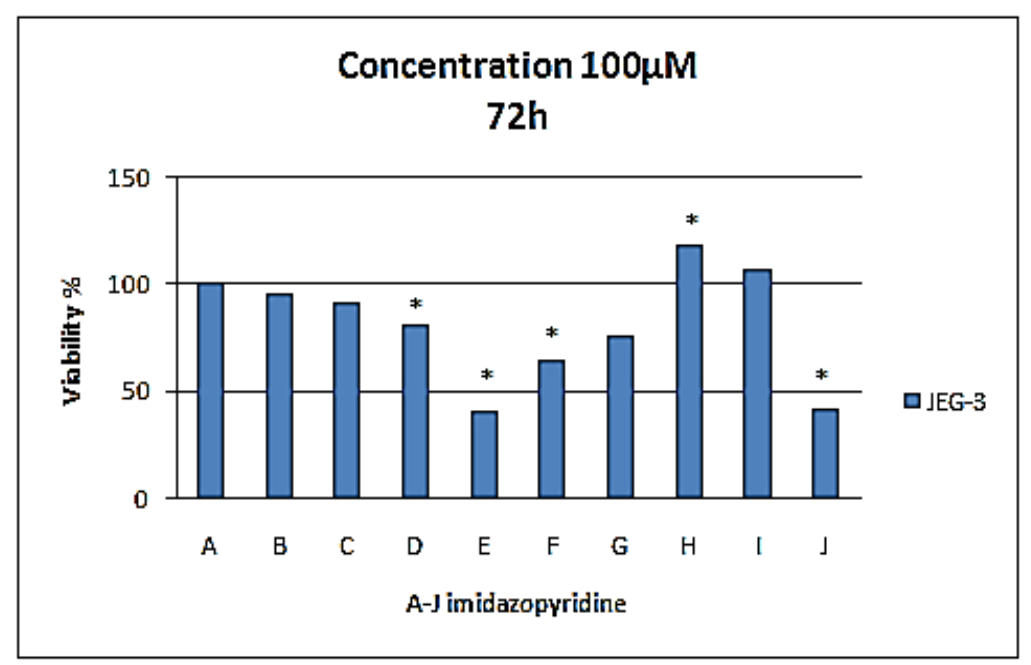

Figure 4. Effect of steroidal imidazoheterocycles $\mathbf{A}-\mathbf{J}$.

Under these experimental conditions, no trend between cytotoxicity and test substance concentration was demonstrated. For this reason, it would be good to repeat the research and better examine the mechanisms responsible for trophoblast's death, using diverse assay (JURISIC et al., 2015).

\section{CONCLUSION}

The obtained results showed that the antiproliferative effect on the JEG-3 choriocarcinoma cell line is brought only by two derivatives of imidazopyridine. This could be mediated probably and mostly because of different substituents at position 17-C atom in the chemical structure of the hormone (hydroxy or methoxy substituent), and by different substituents on the oxygen atom of acetamide in the hormone molecule.

Compounds I and $\mathrm{J}$ are $\mathrm{C}-17$ substituted steroidal N-sulfonylimidates synthesized using $\mathrm{Cu}$-catalyzed azideealkyne cycloaddition. The synthesis and testing of new imidazopyridines and their derivatives can yield effective bioactive substances and potential drugs with an antiproliferative effect on the cancer cell lines.

In this study, the weak antiproliferative activity of newly synthesized imidazopyridine derivatives was demonstrated on the JEG-3 choriocarcinoma cell line of the placenta. In order to better confirm the antiproliferative activity of these derivatives on molecular level, it is necessary to perform research on a large cancer cell line panel.

\section{Acknowledgments}

This work was financially supported by the Ministry of Education, Science and Technological Development, Republic of Serbia, 175056.

\section{References:}

[1] Baviskar, A.T., Amrutkar, S.M., Trivedi, N., Chaudhary, V., Nayak, A., GuchHait, S.K., BanerJeE, U.C., Bharatam, P.V., Kundu, C.N. (2015): Switch in site of inhibition: a strategy for structure-based discovery of human topoisomerase ii $\alpha$ catalytic inhibitors. ACS Medicinal Chemistry Letters 6 (4): 481-485. 
doi: 10.1021/acsmedchemlett.5b00040

[2] Bentley, R.C. (2003): Pathology of gestational trophoblastic disease. Clinical Obstetrics and Gynecology 46 (3): 513-522. doi: 10.1097/00003081-200309000-00004

[3] Chen, L., Chen, X., Chen, X., Hu, Z., LI, X., Su, Y., LI, X., Ge, R.S. (2017): Ziram inhibits aromatase activity in human placenta and JEG-3 cell line. Steroids 128: 114119. doi: 10.1016/j.steroids.2017.09.006

[4] Deep, A., Bhatia, R.K., Kaur, R., Kumar, S., Jain, U.K., Singh, H., Batra, S., KAUSHIK, D., DEB, P.K. (2017): Imidazo[1,2-a]pyridine scaffold as prospective therapeutic agents. Current Topics in Medicinal Chemistry 17 (2): 238-250. doi: $10.2174 / 1568026616666160530153233$

[5] EngueHard-GueIFFIER, C., GUEIFFIER, A. (2007): Recent progress in the pharmacology of imidazo[1,2-a]pyridines. Mini Reviews in Medicinal Chemistry 7 (9): 888-899. doi: $10.2174 / 138955707781662645$

[6] Goel, R., Luxami, V., Paul, K. (2016): Imidazo[1,2-a]pyridines: promising drug candidate for antitumor therapy. Current Topics in Medicinal Chemistry 16 (30): 35903616. doi: 10.2174/1568026616666160414122644

[7] Honkisz, E., Wójtowicz, A.K. (2015): Modulation of estradiol synthesis and aromatase activity in human choriocarcinoma JEG-3 cells exposed to tetrabromobisphenol A. Toxicology in Vitro: an International Journal published in Association with BIBRA 29 (1): 44-50. doi: 10.1016/j.tiv.2014.09.003

[8] Jurisic, V., Radenkovic, S., Konjevic, G. (2015): The actual role of LDH as tumor marker, biochemical and clinical aspects. Advances in Experimental Medicine and Biology 5 (867): 115-24. doi: 10.1007/978-94-017-7215-0_8

[9] Karahoda, R., Kallol, S., Groessl, M., Ontsouka, E., Anderle, P., Fluck, C., StAud, F., AlBrecht, C. (2021): Revisiting steroidogenic pathways in the human placenta and primary human trophoblast cells. International Journal of Molecular Sciences 22 (4): 1704. doi: 10.3390/ijms22041704

[10] Long, B., Tilghman, S.L., Yue, W., Thiantanawat, A., Brodie, A. (1998): The steroidal antiestrogen ICI 182,780 is an inhibitor of cellular aromatase activity. The Journal of Steroid Biochemistry and Molecular Biology 67: 293-304. doi: 10.1016/S0960-0760(98)00122-8

[11] LURAIN, J.R. (2010): Gestational trophoblastic disease I: epidemiology, pathology, clinical presentation and diagnosis of gestational trophoblastic disease, and management of hydatidiform mole. American Journal of Obstetrics and Gynecology 203(6): 531539. doi: 10.1016/j.ajog.2010.06.073

[12] Matić, M., Paunović, M., Ognjanović, B., Štajn, A., Saičić, Z. (2017): Neuropeptide $\mathrm{Y}$ reduces migration capacity of human choriocarcinoma cell line by altering oxidative/antioxidative status. Turkish Journal of Biology 41(2): 292-301. doi: 10.3906/biy-1606-73

[13] Mello, J.B., Ramos Cirilo, P.D., Michelin, O.C., Custódio Domingues, M.A., Cunha Rudge, M.V., Rogatto, S.R., Maestá, I. (2017): Genomic profile in gestational and non-gestational choriocarcinomas. Placenta 50: 8-15.

doi: 10.1016/j.placenta.2016.12.009 
[14] Mosmann, T. (1983): Rapid colorimetric assay for cellular growth and survival: application to proliferation and cytotoxicity assays. Journal of Immunological Methods 65 (1-2): 55-63. doi: 10.1016/0022-1759(83)90303-4

[15] Orendi, K., Kivity, V., Sammar, M., Grimpel, Y., Gonen, R., Meiri, H., Lubzens, E., HuPPERTZ, B. (2011): Placental and trophoblastic in vitro models to study preventive and therapeutic agents for preeclampsia. Placenta 32: 49-54.

doi: 10.1016/j.placenta.2010.11.023

[16] Rassokhina, I.V., Volkova, Y.A., Kozlov, A.S., Scherbakov, A.M., Andreeva, O.E., Shirinian, V.Z., ZAVARZIN, I.V. (2016): Synthesis and antiproliferative activity evaluation of steroidal imidazo[1,2-a]pyridines. Steroids 113: 29-37.

doi: 10.1016/j.steroids.2016.06.001

[17] Samanta, S., Ghosh, A.K., Ghosh, S., Ilina, A.A., Volkova, Y.A., Zavarzin, I.V., Scherbakov, A.M., Salnikova, D.I., Dzichenka, Y.U., SACHEnKo, A.B., ShiRinian, V.Z., HAJRA, A. (2020): Fe(iii)-Catalyzed synthesis of steroidal imidazoheterocycles as potent antiproliferative agents. Organic \& Biomolecular Chemistry 18 (29): 5571-5576. doi: 10.1039/d0ob01241f

[18] Scherbakov, A.M., Komkov, A.V., Komendantova, A.S., Yastrebova, M.A., AndreEva, O.E., Shirinian, V.Z., HajRA, A., Zavarzin, I.V., Volkova, Y.A. (2018): Steroidal Pyrimidines and Dihydrotriazines as Novel Classes of Anticancer Agents against Hormone-Dependent Breast Cancer Cells. Frontiers in Pharmacology 8: 979. doi: 10.3389/fphar.2017.00979

[19] Solano, M.E., ARCK, P.C. (2020): Steroids, pregnancy and fetal development. Frontiers in Immunology 10: 3017. doi: 10.3389/fimmu.2019.03017

[20] XU, H., Zhang, X., Ye, Y., LI, X. (2019): Bisphenol A affects estradiol metabolism by targeting CYP1A1 and CYP19A1 in human placental JEG-3 cells. Toxicology in Vitro: an International Journal published in Association with BIBRA 61: 104615. doi: 10.1016/j.tiv.2019.104615

[21] Zheng, W., Liu, T., Sun, R., Yang, L., An, R., Xue, Y. (2018): Daidzein induces choriocarcinoma cell apoptosis in a dose-dependent manner via the mitochondrial apoptotic pathway. Molecular Medicine Reports 17(4): 6093-6099.

doi: $10.3892 / \mathrm{mmr} .2018 .8604$ 